\author{
Imo Ejeagba Okorie*, Nwokorie Romanus Chukwudi \\ Federal University of Technology, Department of Microbiology, \\ Owerri, Nigeria
}

\author{
Review paper \\ ISSN 0351-9465, E-ISSN 2466-2585 \\ UDC: $620.193 .472 / .479: 582.28$ \\ https://doi.org/10.5937/zasmat21043330

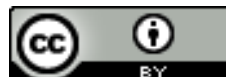 \\ Zastita Materijala 62 (4) \\ $333-339$ (2021)
}

\title{
A review of fungal influenced corrosion of metals
}

\begin{abstract}
The growth of fungi on the surface of metals has great influence on their structural integrity and failure. Their growth on metal surfaces is determined by their secreted metabolites which enable them to adapt to new environmental and nourishment conditions. Although information on the capacity of fungi to adapt to metal surfaces is scarce, most fungi growing on metal surfaces alter the composition of the metals involving it in the process of functional growth and metabolism. Changes in the composition and colour of the metals are some of the evidences confirming that fungus has penetrated the metal surfaces and use it to satisfy its nutritional need with resultant corrosion. In this work we tried to explain different mechanisms of fungal influenced corrosion from different perspectives ranging from the role of biofilms, corrosive media generation by fungal metabolism processes to electrochemical processes generated by fungal growth on metal surfaces. Finally, no single mechanism can conclusively explain all forms of fungal influenced corrosion because every mechanism is unique and applies to individual fungus, its metabolic biproducts or the growth pattern.
\end{abstract}

Keywords: Fungal corrosion, metals, corrosion mechanism, environment, corrosion.

\section{INTRODUCTION}

Fungi are very important factor in environmental ecology, which often determine the duration of the effective use of metal and their alloys [1]. Fungi affects metal and structural parts of buildings accelerating the corrosion rates and deterioration of such materials, the action of which can lead to loss of the esthetic value, integrity and sometimes collapse of such structures. They mostly find their way unto metal surface under the action of adhesion forces and they start to act even at the lowest moisture [2]. In such a way they form chemical bond with the metal. However, not all fungi can survive on metal surface. Most of them die from stress, unfavorable conditions on the metal surface, such as alternating moisture, temperature, physical, chemical and technical parameters [3].

${ }^{*}$ Corresponding author: Imo Ejeagba Okorie

Email: ejeagba.imo@futo.edu.ng

Paper received: 28. 08. 2021.

Paper accepted: 22. 10. 2021.

Paper is available on the website: www.idk.org.rs/journal
According to [2] only fungi that are able to incorporate the metal as a link into their activity chain connecting them with the environment and whose functioning helps reduce the tension between the metal and their vital needs can survive.

Fungi have been implicated in the corrosion of many metals and their alloy used in fabrication and construction of buildings, automobiles and aircrafts [4]. Fungal influenced corrosion (FIC) has been reported for some metals and aluminum alloys exposed to fungi [5]. Differential aeration caused by the adherence of fungal mats can cause crevice corrosion. The reaction of aluminum and its alloys used in aircraft building and the influence of fungi and their metabolites has been studied [1]. Changes in the composition of surface layer of metals or metal alloy is one of the evidences confirming that fungi have penetrated the metal surface and use it to satisfy their nutritional needs. For example, [1] noted that the formation of Aspergillus niger colonies and their colour are determined by oxygen concentration in metal oxide layer. They further observed that the $\mathrm{pH}$ of the 
surface of copper alloys decreases with an increase in quantity of oxygen which, is mostly pronounced in the zone where fungi is growing. Imo et al. [5,6] observed defects and pin holes on the surfaces of mild steel and changes in the color of aluminum coupons exposed to some Aspergillus fumigatus, Acremonium kiliense and Penicillium chrysogenum. In other to reveal the response of fungi developing on metal surface rich in organic substances, [1] exposed $\mathrm{Al}, \mathrm{Fe}, \mathrm{Cu}$ and $\mathrm{Zn}$ plates in close contact with peat compost. The results obtained suggest that fungi developing in the environment actively participate in the process of surface damage and destruction of the metal. Generally, any factor that influences anodic reaction, cathodic reaction or both of a metal can affect the corrosion rate of such metal or the overall process. The factors that can change corrosion rate include $\mathrm{pH}$, temperature and the presence of microorganisms such as fungi.

Unlike bacteria, fungi are the most desiccantresistant microorganisms [7], with the ability to remain active at water activity $\left(a_{w}\right)$ of 0.60 while few bacteria can remain alive at $a_{w}$ below 0.90 . Fungal corrosion via acid generation is always accompanied by the degradation of organic materials such as lubricants [8], and where there is relatively high level of organic material and water. Fungi are able to generate a wide range of organic acids under aerobic conditions. According to Gadd [9], these acids are generated to allow the sequestration of metals from the environment. The impact of organic acids on the corrosion of radioactive waste containers was reviewed by [10] who indicated that both formic and acetic acid was able to promote steel corrosion particularly if present as a vapor. Numerous reports document fungal growth in passenger compartment of inservice aircraft coated with polyurethane paint. Little and Lee [11] documented the following eight fungal genera associated with $\mathrm{H}-3$ aircraft: Pastolotia, Trichoderma, Epicoccum, Phoma, Strephylium, Hormodendrum (also known as Cladosporium), Penicillium and Aureobasidium. These organisms were cultured from virtually all interior surfaces, including primer and polyurethane -coated 2024 T-6 aluminum UNS A92024), fiberglass structures members, caulking, synthetic fabrics, wiring and air conditioning ducts. According to them the concentration of organisms depends on the availability of nutrients and water. They maintained that the fungi did not degrade the polyurethane topcoat, but they derived nutrients from hydraulic fluid, deposited on surfaces during the normal operation of the helicopter and a corrosion inhibiting compound applied to surfaces during maintenance.
According to Little and Lee [11], fungus influenced corrosion of undesignated carbon steel wire rope used in military applications. Laboratory data and field statistics implicated the practice of wrapping in plastic, stored carbon steel highline under humid conditions with microbial influenced corrosion. Fungal growth was observed on interiors of some wooden spools stored outdoors and corrosion was most pronounced on wraps of wire in direct contact with the wooden spool flanges [7]. A. niger and Penicillum sp were isolated from the wooden spool flanges. Large quantities of organic acids by-products induced by these fungi selectively dissolve or chelate copper, zinc and iron forming pits which persist under anaerobic conditions established under fungal mat. Many metals are essential for fungal growth and metabolism [9]. However, metals exact toxic effects in many ways: they can inhibit enzymes, displace or substitute essential metal ions, cause disruption of membranes and interact with the systems that normally protect against the harmful effects of free radicals. The objective of this paper is to present an overview of fungal influenced corrosion which is essentially aerobic in nature and mediated mostly by fungal metabolic activities.

\subsection{Anaerobic corrosion}

Fungi are commonly found in connection with aerobic corrosion. They colonize the metal surface, thus creating oxygen-free environments for anaerobic bacteria, especially SRB [12]. Exopolymeric substances (EPS) excreted by secreted by fungi and some bacteria may contain organic acid high concentration which may stimulate metal deterioration. According to $\mathrm{Gu}$ and Mitchell [13], some groups of aerobic bacteria for example produce strong inorganic acids and thus become very corrosive toward iron.

$$
\begin{aligned}
& 4 \mathrm{OH}^{-}+4 \mathrm{Fe}(\mathrm{OH}) \rightarrow 4 \mathrm{Fe}(\mathrm{OH})+4 \mathrm{e}^{-} \text {anodic } \\
& \mathrm{O}+2 \mathrm{HO}+4 \mathrm{e}^{-} \rightarrow 4 \mathrm{OH}^{-} \text {cathodic } \\
& 4 \mathrm{Fe}(\mathrm{OH})+\mathrm{O}+2 \mathrm{HO} \rightarrow 4 \mathrm{Fe}(\mathrm{OH})_{3} \text { net }
\end{aligned}
$$

In aerobic solution or condition, anodic reaction is similar to the above. The product of the reaction, ferric ions is further hydrolyzed in the presence of oxygen. In presence of biofilms generated by aerobic microorganisms, the corrosion can be enhanced by metabolic reactions taking place in these biofilms as a result creation of oxygen heterogeneities near the metal surface [14], generation of substances that serve as cathodic reactants and generation of corrosive acids among others. Imo et al.[5], studied the corrosion of mild steel and aluminium in the presence of Aspergillus 
fumigatus. The potentiodynamic polarization profile in the presence of $A$. fumigatus showed a rise in corrosion current density $\left(\mathrm{I}_{\text {corr }}\right)$ from 187.95 and $153.5 \mu \mathrm{A} / \mathrm{cm}^{2}$ (in the absence of the fungi) to 279.4 and $201.2 \mu \mathrm{A} / \mathrm{cm}^{2}$ (in the presence of the fungi) for mild steel and aluminium respectively. The gravimetric analysis further revealed that the corrosion and weight loss of the metals increased with time.

\section{MECHANISMS OF FUNGAL CORROSION}

There is no universal mechanism of microbial influenced corrosion. Instead, many mechanisms exit and some of them have been described and quantified better than others [14]. The mechanism of fungal corrosion of metal is evident on how the growth, adhesion and production of metabolites interfere with the corrosion processes. According to Beech [15] it is known that mechanical and structural factors all play a role, both biotic and abiotic in nature, and these may all work in concert to cause and sustain microbial influenced corrosion.

\subsection{Formation of biofilms that enables the emergence of aeration cells}

Fungi and other microorganisms influence the corrosion of metal through the formation of differential aeration cells at different locations on the metal surface [14]. The effect of different concentrations of oxygen at different locations on the metal surface can be caused by the active consumption of oxygen by microorganisms in biofilms not uniformly distributed on the metal surface. It can also be caused by passive mechanism in which oxygen access to some areas is physically obstructed. According to Lewandowski and Beyenal [14] if the oxygen concentrations at two adjacent locations on an iron surface are different, then the cell potentials at these locations are different as well. The location where the oxygen concentration is higher will have a higher potential (more cathodic) than the location where the oxygen concentration is lower (more anodic). The difference in potential will give rise to current flow from the anodic locations to cathodic locations and to the establishment of corrosion cell. This is the mechanism of differential aeration cells, and the prerequisite to this mechanism is that the concentration of oxygen varies among location [1618]. According to [19], many measurements using oxygen microsensors have demonstrated that oxygen concentrations in biofilms can vary from one location to another. For example, fungal growth on metal surface can partially seal the surface leading to generation of differential aeration cells. These will result to the isolation of a certain part of the metal surface and the establishment of electrochemical corrosion.

\subsection{Formation of corrosive media due to acids generation}

Fungi generally acidify their microenvironment through a number of mechanisms, which include the excretion of protons and organic acids, respiratory carbon dioxide $\left(\mathrm{CO}_{2}\right)$ which can in turn result in carbonic acid formation. Some fungi can excrete a variety of other metal-complexing metabolites such as siderophores, carboxylic acids, amino acids and phenolic compounds [20]. Videla [21], observed that the acids produced by fungi are damaging to metal and their alloys. Fungi are able to oxidize ferrous iron to ferric hydroxide, which is precipitated on metal surface. Fungi can also reduce insoluble $\mathrm{Fe}$ (III) to $\mathrm{Fe}$ (II) as a result of their growth and metabolic processes. They are therefore able to induce or influence the corrosion of metals through the reduction and removal of passive oxide films from metal surfaces. Based on their metabolic activities, fungi can also oxidize metals. Metal oxidizing fungi generally produces aggressive compounds that induce corrosion damage. Such metabolic products include organic or inorganic acids like sulfuric acid which deteriorates metals integrity and cause serious corrosion failures. For example, the corrosive effects of $A$. fumigatus growth on metal surface can be linked to two mechanisms of uptake of iron exhibited by the fungus; reductive iron acquisition and siderophore-mediated iron uptake.

\subsection{Modification on the resistance of films exiting on the metal surfaces caused by products of fungal metabolism}

Biofilms facilitates the removal of protective films on the metal surface when they detach [22]. Videla [12], observed that fungi grow rapidly on the polarized metal surface. Their continual growth on metal surface generates pressure on the metal leading to the rupture of surrounding coatings. Copper-nickel alloys in seawater can be colonized by fungi and other organisms after extended periods of exposure despite their perceived antifouling properties. The detachment of the biofilms can cause the protective coating of metals to fall off. Videla [21], observed that biofilm formation on metal surfaces is mostly conditioned by the chemical nature and distribution of inorganic passive layers and by the elemental composition of the substratum [23]. They further observed that several months after exposure; fungal mycelia can 
be found entrapped between layers of corrosion products and EPS in a layered structure. Biofilm detachment might facilitate the removal of inorganic passive layers, resulting in a patchy distribution of the biofilm which can further lead to corrosion. Mat of fungal mycelia, observed sometimes as the predominant biofouling species, can facilitate passive layer detachment through adhesive effects developed at the fixation points and assisted by water flow velocity [22] or through other physical means.

\subsection{Direct influence on the speed of cathodic and anodic reactions}

The existence of a fungal biofilm can impede the diffusion of chemical species-both into and out of the biofilm-thus producing localized chemical environments that are significantly different from the bulk. These localized environments can in turn, greatly affect the underlying corrosion and also directly influence the speed of cathodic and anodic reactions [4]. By inhibiting the diffusion of the corrosive chemicals away from the metal surface, the biofilm can effectively act as a concentration multiplier [24]. The organic acid generated by fungi in aerobic region is potentially made more potent when encapsulated beneath a biofilm than otherwise. In addition to concentrating the organic acids, the biofilm can also concentrate the corroded ferrous ions, a key factor in microbial influenced corrosion.

Xiaohui and Ling [25] outlined some electrochemical processes induced by fungi growth to include: the corrosive materials excreted by fungi during their growth and metabolic processes such as enzymes and acids. These materials will cause the corrosion of steel, copper, aluminium and other metals. In some cases, fungal growth seals off the surface of metal leading to the formation of bubbles. This will isolate parts of the metal surface resulting to the establishment of partial electrochemical corrosion.

\subsection{Growth of fungi on metal surfaces}

Fungi grow rapidly under polarized layer. This leads to the generation of pressure on and around the metal surface resulting to rupture. Studies of morphological changes on the metal surfaces after exposure to $A$. fumigatus for sixty days showed prominent corrosion spots on the surfaces of the mild steel with more of these corrosion defects centered on the edges [5]. They observed that the growth of the fungi on the metal was proportional to corrosion rate and the intensity of the corrosion spots observed. The study using potentiodynamic polarization technique (Table 1 ) on $A$. fumigatus, $P$. chrysogenum and $A$. kiliense influenced corrosion of mild steel and aluminium $[5,6,26]$ revealed that corrosion current $\left(\mathrm{I}_{\text {corr }}\right)$ increased in the presence of the fungi after 60 days incubation relative to the control (in the absence of fungi). This suggests that the growth of fungi on metals increase their electrochemical potentials which in turn results to increase in $\mathrm{I}_{\text {corr }}$ and eventual corrosion of the metal. The authors observed that increase in $I_{\text {corr }}$ was due to the influence of fungi on the rate of the anodic and cathodic reactions. Furthermore, the gravimetric results of corrosion behavior of mild steel and aluminium in the absence of the above fungi showed that the corrosion rate $(C R)$ and weight loss $(\Delta \mathrm{W})$ loss date were lower compared to the value obtained when the metals were exposed to fungi. For example, the cumulative CR ( $\Sigma C R)$ observed when mild steel was exposed for 60 days in the absence of any fungi was $1.74 \pm 0.02 \mathrm{mpy}$ while $\Sigma C R$ observed when same metal was exposed to $A$. kiliense, $A$. fumigatus and $P$. chrysogenum was $6.51 \pm 0.19 \mathrm{mpy}, 7.85 \pm 0.91 \mathrm{mpy}$ and $7.58 \pm 0.79 \mathrm{mpy}$ respectively [5].

Another mechanism of fungi corrosion is by depolarization. If fungi grow on metals, they not only can consume for example, the nitrate and sulfur accumulated on the eroded pole but also hydrogen, oxygen and other gaseous products formed on the metal surface thereby continuing hitherto suspended corrosion process. Videla and Harrera [22] summarized the mechanisms of fungal influenced corrosion for carbon steel and aluminum alloys exposed to hydrocarbon fuels to include: local increase in proton concentration derived from organic acidic metabolism, increase in oxidizing characteristics of the medium which in turn favors pitting attack on the metal, metabolite production by the fungi which decreases the surface energy of the interface passive film or electrolyte, microbial adhesion that results to metal dissolution and finally microbial uptake of fuel additives including corrosion inhibitors. Fungi can produce chelators known as siderophores. Siderophores are low molecular weight compounds with high affinity for iron which solubilize ferric ions and transport these ions into the fungi cell for growth and activity. Siderophores can uptake the iron from the metal for growth and activity of the fungi. Siderophores iron interaction and the uptake of iron from metals can enhance corrosion processes. The growth of fungi in coating, rust inhibitors or grease will make the protective coatings of such metals to fall off thereby exposing the metals to more severe corrosion. 


\section{FUNGAL CORROSION CONTROL METHODS}

The methods employed mostly involved in the prevention of fungal corrosion act by inhibiting the growth of the fungus and changing the environment in which the corrosion process occurs in order to avoid the adaptation of fungi. Physical (cleaning procedures) and chemical methods (sanitization through the use of biocides and antifouling coatings such as inks or corrosion inhibitors) are used generally combined to improve the procedure [22] Physical methods include flushing, which perhaps is the simplest, although of limited efficacy.

The most common chemical method of corrosion and biofouling control in industrial water systems is the use of biocides [22]. Corrosion inhibitors can be either oxidizing compounds (e.g., chromate, nitrate and molybdate), which encourages the production of low solubility corrosion product films on the metal surface or non-oxidizing toxicants (carbonates, silicates and phosphates), which form protective films or adsorption type inhibitors (highly polar, anionic organic molecules) which absorb on metal [12] Chlorine, ozone and bromine are three typical oxidizing agents of industrial use. Non-oxidizing biocides are reported to be more effective than oxidizing biocides for overall control of algae, fung and bacteria as they are more persistent, and many of them are $\mathrm{pH}$-independent [27]. Combinations of oxidizing and non-oxidizing biocides or of two non-oxidizing biocides are often used to optimize the microbiological control of industrial water systems. According to Videla and Herrera [28], dichloromethyl hydanton, chlorinated isocyanurates, calcium hyochlorite (oxidizing biocides) and acrolein, chlorinated phenols, quaternary ammonium compounds, methylene bisthiocyanate, hexachlorodimethyl carbonate (non-oxidizing biocides) are used to retard the growth of different types of microorganisms.
According to Uhlig [29], cathodic protection CP can prevent all kinds of corrosion; including microbial influenced corrosion, if adequate potentials are sustained. The technique has also been applied to tanks, clarifiers and heat exchanger.

The known hazardous effects of most synthetic inhibitors and the need to develop cheap, nontoxic and eco-friendly process have motivated researchers to focus on the use of natural products [30]. The environmental toxicity of inorganic corrosion inhibitors has promoted the search for green corrosion inhibitors as they are biodegradable, do not contain heavy metals or other toxic compounds. In addition to being environmentally friendly and ecologically acceptable, plant products are inexpensive, readily available and renewable [3134].

Tannins, organic acids, alkaloids, pigments and proteins from plants are known to inhibit metal corrosion [35,36]. Imo et al. [5] inhibited the growth of Aspergillus fumigatus with the extract of Piper guineense. They attributed the anti-corrosion activity of the extract to the phytochemical constituents of the extract which often bear similar molecular, electronic structure with organic corrosion inhibitors as well as antimicrobial properties

The adhesive protein from the marine mussel Mytilus edulis and the bovine serum albumin (BSA) were both absorbed on carbon steel and were able to inhibit corrosion [37]. Plant products have shown antimicrobial activity and studies in the use of extracts or isolated compounds to combat humanpathogens and phytopathogenic bacteria and microorganisms involved in corrosion are well documented [38-40]. The activity of an aqueous extract of Brassica nigra on planktonic and sessile Pseudomonas sp., the fungus Aspergillus fumigatus and a mixture of SRB revealed a promissory biocidal action against microorganisms frequently found in industrial biofilms [21].

Table 1. Polarization data for mild steel and aluminium in the presence and absence of fungi

Tabela 1. Podaci polarizacije za meki čelik i aluminijum u prisustvu i odsustvu gljivica

\begin{tabular}{|l|c|c|c|c|c|c|c|c|}
\hline \multirow{2}{*}{ Fungi } & \multicolumn{2}{|c|}{$\mathrm{I}(\mathrm{IA} / \mathrm{cm} 2)$} & \multicolumn{2}{c|}{ Ecorr $(\mathrm{mV})$ Vs SAC } & \multicolumn{2}{c|}{ la } & \multicolumn{2}{c|}{ ic } \\
\cline { 2 - 10 } & Mild steel & Aluminium & Mild steel & Aluminium & Mild steel & Aluminium & Mild steel & Aluminium \\
\hline $\begin{array}{l}\text { Acremonium } \\
\text { kiliense }\end{array}$ & 223.0 & 183.7 & -417.3 & -795.0 & 122.7 & 100.3 & 100.6 & 121.4 \\
\hline $\begin{array}{l}\text { Aspergillus } \\
\text { fumigatus }\end{array}$ & 279.4 & 201.2 & -485.4 & -796.4 & 115.1 & 97.6 & 75.1 & 109.8 \\
\hline $\begin{array}{l}\text { Penicillium } \\
\text { chrysogenum }\end{array}$ & 258.6 & 184.6 & -490.2 & -734.5 & 107.0 & 90.6 & 69.5 & 104.6 \\
\hline Control & 187.9 & 153.5 & -491.8 & -701.6 & 105.3 & 89.5 & 69.2 & 100.3 \\
\hline
\end{tabular}

Legend: $I_{\text {corr }}=$ Corrosion current density; $\mathrm{E}_{\text {corr }}=$ Corrosion potential; ia =Anodic current; ib=Cathodic 


\section{CONCLUSION}

Studies have shown that fungi can influence the corrosion of metal and their alloys. Fungi are able to generate a wide range of organic acids under aerobic conditions because they can proliferate in humid environments assimilate low molecular weight molecules and elements from metal surfaces. The mechanisms of fungal corrosion are diverse and there are no unified mechanisms. This is because corrosion process by each fungus is distinct depends on the specific organism growing in the environment, chemical nature of the environment and the electrochemical properties of the metals.

\section{REFERENCE}

[1] A.Lugauskas, K.Leinartas, A.Grigucevičienè, A Selskienè, E.Binkauskienè (2008) Possibility of micromycetes detected in dust to grow on metal $(\mathrm{AL}, \mathrm{Fe}, \mathrm{Cu}, \mathrm{Zn})$ and polyaniline-modified $\mathrm{Ni}$, Ecology, 54(3), 149-157.

[2] A.Lugauskas, P.Igoris, R.Rimantas, G.Asta, S. Aušra, P.Vidas (2009) The influence of micromycetes on the corrosion behaviour of metals $(\mathrm{Cu}$, $\mathrm{Zn}$ ) in environments polluted with organic substances, Chemija, 20(3), 141-153.

[3] E.Juzeliunas, R.Ramanauskas, A.Lugauskas, K. Leinartas, M.Samuleviviciene A.Sudavicius, R. Juskenas (2007) Microbially influenced corrosion of zinc and aluminum-two-year subjection to influence of Aspergillus niger, Corrosion Science, 49, 40984112.

[4] I.B.Beech, J.Sunner (2004) Biocorrosion: towards understanding interaction biofilms and metals, Current Opinion in Biotechnology, 15, 181-186.

[5] E.O.Imo, J.C.Orji, C.O.Nweke (2018) Influence of Aspergillus fumigatus on corrosion behaviour of mild steel and aluminium, International Journal of Applied Microbiology and Biotechnology Research, 6, 61-69.

[6] E.O.Imo, J.C.Orji, C.O.Nweke (2019) Fungal influenced corrosion of aluminium in the presence of Acremonium kiliense, International Journal of Applied Microbiology and Biotechnology Research 7, 1-6.

[7] B.Little, R.Ray (2002) A prospective on corrosion inhibition by biofilms, Corrosion, 58, 424-428.

[8] B.Little, R.Staehle, R.Davis (2001) Fungal influenced corrosion of post-tensioned cables, International Biodeterioration and Biodegradation, 47, 71-77.

[9] G.M.Gadd (2010) Metals, minerals and microbes: geomicrobiology and bioremediation, Microbiology, $15,609-643$

[10] B.M.Rosales (1985) Corrosion measurement for determining the quality of maintenance in jet fuel storage. In:Dexter. S.C., Videla, H.A. (eds) Proceeding of the Argentine-USA Workshop on Biodeterioration. Sao Paulo, Brazil. Aquatic Quimica, p.135-143.
[11] B.Little, J.S.Lee (2007) Microbiologically Influenced Corrosion. Hoboken, N.J., USA, John Wiley and sons.

[12] H.A.Videla (2001) Microbially influenced corrosion: an update overview, International Biodeterioration and Biodegradation, 48, 176-201.

[13] J.D.Gu, R.Mitechell (2000) Biodeterioration. In: Dworkin, M., Falkow, S., Rosenberg, E., Scheifer, K.H. and Stackebrandt, E. (ed). Prokaryotes: An Evolving Electronic Resourse for the Microbiological Community. Springer-Verlag, New York.

[14] Z.Lewandowski, H.Beyenal (2008) Mechanisms of microbially influenced corrosion, Springer Series on Biofilms, 8, 1-2.

[15] B.Beech (2003) Sulfate-reducing bacteria in biofilms on metallic materials and corrosion, Microbiology Today, 30, 115-117.

[16] N.Acuna, B.O.Ortega-Morales, A.Valadez-Gonzalez (2006) Biofilms colonization dynamics and influence on the corrosion resistance of austenitic UNSS31603 stainless steel exposed to Gulf of Mexico seawater, Mater. Biotechnology, 8, 62-70.

[17] W.H.Dickinson, Z.Lewandoski (1998) Electrochemical concepts and techniques in the study of stainless-steel ennoblement, Biodegradation, 9, 1121.

[18] M.A.Hossain, C.R.Das (2005) Kinetic and thermodynamic studies of microbial corrosion of mild steel specimen in marine environment, Journal of Indian Chemical Society, 82, 376-378.

[19] Z.Lewandowski, H.Beyenal (2007) Fundamentals of Biofilm Research. CRC Press, Boca Raton, Florida.

[20] W.Burgstaller, F.Schinner (1993) Leaching of metals with fungi, Journal of Biotechnology, 27, 91116.

[21] H.A.Videla (2003) Biocorrosion and biofouling of metals and alloys of industrial usage: Present state of art at the beginning of new millennium, Revista de Metalurgia, 1, 256-264.

[22] H.A.Videla, L.K.Herrera (2005) Microbiologically influenced corrosion: Looking to the future, International Microbiology, 8(3), 169-180.

[23] D.Cetin, M.L.Aksu (2003) Corrosion behavior of low-alloy steel in the presence of Desulfotomaculum $s p$, Corrosion Science, 51, 1584-1588.

[24] T.Rohwerder. T.Gehrke, K.S.Kinzler (2003) Bioleaching review part A: Progress in bioleaching: fundamentals and mechanisms of bacterial metal sulfide oxidation, Applied Microbiology Biotechnology, 63, 239-248.

[25] W.Xiaohui, W.Ling (2006) Measures and Test Techniques for fungus resistance to aircraft materials and equipment. $25^{\text {th }}$ International Congress of the Aeronautical Sciences, ICAS 2006.

[26] E.O.Imo, J.C.Orji, C.O.Nweke (2020) Impact and corrosion behavior of mild steel in the presence of Penicillium chrysogenum, International Journal of Coal, Geology and Mining Research, 2(1), 34-44.

[27] H.A.Videla (2002) Prevention and control of biocorrosion, International Biode-terioration and Biodegradation., 49, 259-270.

[28] H.A.Videla, L.K.Herrera (2004) Biocorrosion. In Vazquez-Duhalt, R., Quintero-Ramirez, R. (eds), Petroleum biotechnology. Developments and 
perspectives. Elsevier, Amsterdam, The Netherlands, p.193-218.

[29] H.H.Uhlig (2011) Corrosion hand book. Third Edition. Edited by R. Winston Revie. John Wiley and Sons Inc.

[30] B. E. Amitha-Rani, J. B. Bharathi-Bai (2012) Green inhibitors for corrosion protection of metals and alloys: An overview, International Journal of Corrosion., 10, 70-80.

[31] G.Gunasekaran, L.R.Chuhan (2005) Eco-friendly for corrosion inhibition of mild steel in phosphoric acid medium, Electrochimica Acta, 49, 43874395.

[32] A.Y.El-Etre, M.Abdallah, Z.E.El-Tantawy (2006) Corrosion inhibition of some metals using Lawsonia extract, Corrosion Science, 47, 385-395.

[33] Y.Li, P.Zhao, Q.Liang, B.Hou (2005) Beberine as a natural source inhibitor for mild steel in $1 \mathrm{M} \mathrm{H}_{2} \mathrm{SO}_{4}$, Applied Surface Science, 252, 1245-1253.

[34] A.M.Abdel-Gaber, B.A.Abd-El-Nabey, I.M Sidahmed, M.A.El-Zayady, M. Saadaway (2006) Inhibitive action of some plant extracts on the corrosion of steel in acid media, Corrosion Science, 48, 2765-2779.
[35] A.Singh, E.E.Ebenso, M.A.Quraishi (2012) Corrosion inhibition of carbon steel in $\mathrm{HCl}$ solution by some plant extracts, International Journal of Corrosion, Article ID 897430.

[36] K.Merritt, S.A.Brown (2004) Effect of proteins and $\mathrm{pH}$ on fretting corrosion and metal ion release, Journal of Biomedical Materials Research, 22, 111120.

[37] F.Zhang, J.Pan, P.M.Claesson (2011) Electrochemical and AFM studies of mussel adhesive protein (Mefp-1) as corrosion inhibitor for carbon steel, Electrochemica Acta, 56, 1636-1645.

[38] R.J.W.Lambert, P.N.Sjandamis, P.J.Coote, G.J.E.Nychas (2001) A study of minimum inhibitory concentration and mode of action of oregano essential oil, Journal of Applied Microbiology, 91, 453-462.

[39] C.C.Albuquerque, T.R.Camara, R.L.R.Mariano, L. Willadino, C.M.Junior (2006) Antimicrobial action of the essential oil of Lippia gracilis Schauer, Brazilian Archives of Biology and Technology, 49, 453-462.

[40] R.M.P.B.Costa, A.F.M.Vaz, M.L.V.Oliva, M.T.S Correia (2010) A new Phthirusa pyrifolia leaf lectin with antimicrobial properties, Process Biochemistry, $45,526-533$.

\section{IZVOD}

\section{PREGLED GLJIVIČNE KOROZIJE METALA}

Rast gljiva na površini metala ima veliki uticaj na njihov strukturni integritet i kvar. Njihov rast na metalnim površinama određen je izlučenim metabolitima koji im omogućavaju da se prilagode novim uslovima životne sredine $i$ ishrane. lako su informacije o sposobnosti gljiva da se prilagode metalnim površinama oskudne, većina gljiva koje rastu na metalnim površinama menjaju sastav metala koji ih uključuju u proces funkcionalnog rasta i metabolizma. Promene u sastavu metala $i$ promene boje neki su od dokaza koji potvrđuju da je gljiva prodrla u metalne površine i koristi je za zadovoljavanje svojih nutritivnih potreba sa rezultujućom korozijom. U ovom radu pokušali smo objasniti različite mehanizme korozije pod uticajem gljivica iz različitih perspektiva, od uloge biofilmova, stvaranja korozivnih medija putem procesa metabolizma gljiva do elektrohemijskih procesa nastalih rastom gljivica na metalnim površinama. Konačno, nijedan jedinstven mehanizam ne može u potpunosti objasniti sve oblike korozije izazvane gljivicama, jer je svaki mehanizam jedinstven i primjenjuje se na pojedine gljive, njihove metaboličke nusproizvode ili obrazac rasta.

Ključne reči: gljivična korozija, metali, mehanizam korozije, životna sredina, korozija.

Pregledni rad

Rad primljen: 28. 08. 2021

Rad prihvaćen: 22. 10. 2021.

Rad je dostupan na sajtu: www.idk.org.rs/casopis

(C) 2021 Authors. Published by Engineering Society for Corrosion. This article is an open access article distributed under the terms and conditions of the Creative Commons Attribution 4.0 International license (https://creativecommons.org/licenses/by/4.0/) 